\title{
To improve science literacy, researchers should run for school board
}

\author{
Jon D. Miller
}

This century will bring exciting biomedical advances thanks to stem cells and genetic engineering. If scientists want the public to grasp the meaning of these developments, they need to start getting personally involved in improving the education system.

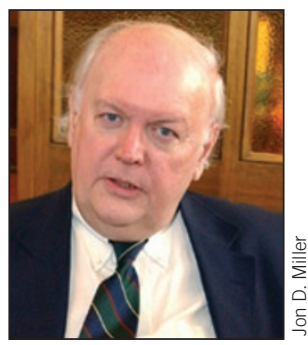

Given the complexity of modern medicine, it's crucial for all people to be biologically literate so that they can make intelligent decisions about themselves and their families as consumers and patients. Individuals who do not understand the nature of a virus, for example, may make bad judgments about protecting their health with vaccinations or about taking medical screening precautions. But the importance of science literacy goes beyond the clinic: it's equally important that the public understand science so that, when people enter the voting booth, they can make informed judgments on public policy issues involving basic biological research.

At the very heart of its meaning, biological literacy refers to the ability to understand the basic conceptual constructs of the life sciences, such as the nature of a cell, the function of DNA and the development of life over billions of years through natural selection. Individuals who understand these basic constructs will have the ability to parse arguments about the promises and risks of various kinds of genetic manipulations and the potential results of embryonic stem cell research-along with the hundreds of similar controversial medical interventions that will doubtless emerge in the $21^{\text {st }}$ century. This understanding needed may not rise to the degree of scientific knowledge required for bench work, but it should still reach a level at which the individual can grasp the full meaning of a biomedical news story in the New York Times Science Times in the US, Science \& Vie in France, or similar publications elsewhere.

Surveys suggest that there is still a long way to go. The periodical Eurobarometer polls conducted for the European Commission have found mediocre scientific literacy as well as great disparity among various countries in the continent. In the 2005 Eurobarometer report, whereas $35 \%$ of Swedes were deemed scientifically literate, only $9 \%$ of people in Ireland qualified as such. We should not accept such low levels of fundamental knowledge in any modern democracy.

In my regular surveys of people living in the US, I have found that only about one in five adults have sufficient biological literacy to perform their roles as patient, parent or citizen, using simple measures of the understanding of basic constructs such as DNA or a stem cell. There are signs of hope: in my 2007 National Science Foundation-funded survey of 1,400 randomly selected people, $13 \%$ could provide a correct openended definition of a 'stem cell', up from $8 \%$ in a survey of 1,600 people in 2003. However, over the same timeframe the fraction of people who agreed with the statement that "all plants and animals have DNA" slipped from $83 \%$ to $77 \%$.

Why are levels of biological literacy so low? The answer is different for the US and the EU. In the US, the primary source of funding for schools comes from property taxes, and this means that money for education is too limited and too unevenly distributed. Last summer the data released by the US Census Bureau indicated that per-student spending in the country's public education system averaged a meager $\$ 10,259$. And there is a tremendous amount of discrepancy between states, with Utah and Idaho, for example, spending as little as $\$ 5,765$ and $\$ 6,931$, respectively. This lack of funding, combined with the threat of creationist challenges to science education and poor recruitment of teachers, has taken a toll on the classroom. In the longer term, any public school system built on property taxes is doomed to mediocrity.

In Europe, the life sciences have been taught somewhat better in secondary schools than in the US, as shown by test results from surveys such as the OECD International Student Assessment, in which countries such as Finland scored high. However, European universities do not require a year of general education, and students who do not major in a science field may have no additional exposure to science courses after secondary school. As a result, a majority of European adults have agreed that "genetically modified tomatoes have genes whereas regular tomatoes do not" when asked by the Eurobarometer survey in recent years.

So what should we do to address this problem? First, it is important for the US to continue its commitment to general education at the university level and for Europe to move to a four-year university curriculum that includes strong general education requirements in science. Second, it is necessary to recognize that learning about science is a lifelong process. Few adults today studied stem cells as students, but in the $21^{\text {st }}$ century we will need to understand these issues. Universities and other institutions need to help build a sustainable system of lifelong learning.

To truly address the lack of science literacy, all countries need to redouble their efforts to improve life sciences instruction in the middle school and secondary school years. The US legislation of recent years that mandates student testing and accountability is a step in the right direction, but this should be coupled with enriched curriculums and improved teacher preparation. And even though organizations such as the Federation of American Societies for Experimental Biology and the American Chemical Society have devoted resources to developing better textbooks, we need more than just better books: we need scientists themselves to get directly involved with secondary school education.

This is not a suggestion that I make in the abstract. Two decades ago I ran for the school board in the district where my family lived-and won a seat. In my few years on the school board, I found a real opportunity to advocate for improved curriculum in the sciences and improved general financial support for the school. I championed a requirement for a year of algebra for all students in high school, and although this measure was not immediately implemented, there were still gains toward this goal. On the basis of this experience, I have run a workshop in recent years at the annual meeting of the American Association for the Advancement of Science designed to expose researchers to the possibility of seeking election to their local school boards.

The process of running for a school board takes energy and dedication. It involves securing a list of registered voters, getting signatures on petitions and campaigning door to door, among other steps. And of course, once the seat is won, the challenges of public service begin. But it is only when researchers actively involve themselves in the education system in this way that we can expect science literacy to improve.

Jon D. Miller is director of the International Center for the Advancement of Scientific Literacy at the University of Michigan, Ann Arbor, USA. 